Proc. Estonian Acad. Sci. Geol., 1996, 45, 4, 203-215

\title{
MINERAL COMPOSITION OF THE DERMAL SKELETON OF DEVONIAN FISHES FROM ESTONIA
}

\author{
Jüri NEMLIHER ${ }^{\mathrm{a}}$, Tuuli LAAS ${ }^{\mathrm{b}}$, Toivo KALLASTE ${ }^{\mathrm{a}}$, \\ and Ivar PUURA ${ }^{\mathrm{a}, \mathrm{c}}$
}

a Geoloogia Instituut (Institute of Geology), Estonia pst. 7, EE-0001 Tallinn, Eesti (Estonia)

b Eesti Kaardikeskus (Estonian Map Centre), Mustamäe tee 33, EE-0006 Tallinn, Eesti

(Estonia)

c Institutionen för Geovetenskap, Uppsala Universitet (Institute of Earth Sciences, Uppsala University), Dept. of Historical Geology and Palaeontology, Norbyvägen 22, S-75236 Uppsala, Sverige (Sweden)

Presented by E. Pirrus

Received 25 May 1996, accepted 3 June 1996

Abstract. Twenty-eight samples of the dermal skeleton of Middle Devonian fishes from six localities of Estonia were studied by means of X-ray diffraction analysis. The fish fossils are composed of carbonate fluorapatite with the lattice parameters $a=9.360-9.374 \AA$ and $c=6.891-$ $6.895 \AA$. The scanning electron microscopy (SEM) and energy dispersive X-ray spectroscopy (EDX) revealed that the fossil fish fragments had precipitated by various phases of authigenic apatite. In our interpretation, the mineral part of the original organo-phosphatic skeleton of the Devonian fishes could be represented by carbonate hydroxyapatite, like in Recent vertebrates. The observed carbonate fluorapatite composition is regarded as a result of diagenetic alteration, in particular, by precipitation of authigenic apatite.

Key words: XRD, SEM, authigenesis, apatite, fishes, biomineralization, Middle Devonian, Estonia.

\section{INTRODUCTION}

The first study of the composition of placoderm fish fragments from a classic locality, the Aruküla caves near Tartu, was carried out by Heintz (1934). Comparing the chemical composition of the placoderm fishes with bones of Recent Perca fluviatilis and Bos taurus, he concluded that the 
chemical composition of the Devonian fishes was very similar to that of Recent vertebrate bones, with the exception of higher fluorine and iron oxide contents in fossil skeletal fragments. He suggested that the more than seven times higher $\mathrm{F}$ content in the fossil bones could be explained by secondary changes. He also pointed out that the skeletal fragments, secondarily enriched with iron oxides, had yellow-brown colour (Heintz, 1934, p. 9).

Sidorenko \& Chernova (1962) carried out an X-ray diffraction (XRD) study of 95 samples of skeletal fragments of fossil fishes ranging from the Devonian to Recent in age, among them 54 Devonian samples. They reported a wide range of variation of the lattice parameters of skeletal apatite, concluding that the skeletal tissues of fossil fishes are composed of a variety of apatite species, ranging from hydroxyapatite to carbonate fluorapatite.

Ivanov \& Pavlov (1988) studied the apatite mineralogy of histologically different skeletal elements of the fishes from the Middle and Upper Devonian of NW Russia and Latvia. The results obtained displayed the variation range of 9.34-9.40 $\AA$ for the lattice parameter $a$ and 6.88$6.91 \AA$ for c. In a further study, Ivanov et al. (1992) showed that the orientation of apatite crystallites in fossil agnathan and arthrodire fishes was similar to that in Recent turtle carapace, concluding that the fossilization of bony plates should have proceeded without reorientation of the crystallites.

The purpose of this study is to document the mineral composition of the Devonian fishes on a rich material from different localities in order to reveal the role of diagenetic changes in the formation of the final composition of the fossil skeletal fragments.

\section{SAMPLES AND LOCALITIES}

A rich collection of Devonian fishes is housed in the Institute of Geology, Tallinn. The twenty-eight samples of the dermal skeleton fragments studied originate from six Middle Devonian localities in Estonia, stratigraphically ranging from the Narva Stage to the Gauja Stage (Fig. 1). The scales of two Recent fishes, a shark (Isurus oxyrinchus) and a bream (Abramis brama), were studied for comparison. The localities are reviewed below in a tentative descending age order.

The Gorodenka localities (1 and 2) are situated $35 \mathrm{~km} \mathrm{SW}$ of Narva, on the Gorodenka Brook, the left tributary of the Narva River. The distance of the Gorodenka 1 locality from the Gorodenka Forestry near the mouth of the Gorodenka Brook is $750 \mathrm{~m}$ from a bird's eye view. The continuous sequence of siltstones and clays extends to the Gorodenka 2 





locality, located $600 \mathrm{~m}$ farther upstream. This sequence, exposed in a total thickness of about $5 \mathrm{~m}$, has been assigned to the Kernave Member of the Narva Stage. The lower part of the sequence is accessible in the Gorodenka 1 locality. Our samples from this locality originate from a $0.55 \mathrm{~m}$ thick interval of grey clayey siltstone, $2.2 \mathrm{~m}$ above the base of the exposed sequence (bed 5 by Kleesment et al., unpubl.). This interval yields numerous fish fossils and fragments of lingulid brachiopods. The level, sampled in the Gorodenka 2 locality, is a $0.25 \mathrm{~m}$ thick interval of brownish-grey sandstone, $0.6 \mathrm{~m}$ above the top of bed 5 (bed 7 by Kleesment et al., unpubl.). A conglomerate, containing pebbles and fragments of clay, siltstone, and dolomitic marl, occurs at the base of this interval. This interval contains rounded skeletal fragments of fishes.

The Aruküla caves are located in the environs of the town of Tartu, about $700 \mathrm{~m}$ north of the Jaani cemetery at the present town boundary, on the left bank of the ancient valley of the Emajõgi River. The fish samples originate from the basal part of an interval of white cross-bedded quartzose sandstone, $1.35 \mathrm{~m}$ thick, with up to $0.3 \mathrm{~m}$ thick lenses of clayey bluish-grey sandstone. This interval underlies $0.5 \mathrm{~m}$ thick reddish, crossbedded sandstone and overlies a $0.01-0.02 \mathrm{~m}$ thick bluish clay layer. The latter is underlain by hard dolomite, with intercalations of clay, exposed in a thickness of $0.15 \mathrm{~m}$ (Mark, 1952). The described sequence of sandstones, clays, and dolomites in the Aruküla caves is referred to the Viljandi Beds of the Aruküla Stage (Kleesment, 1994). This is probably the best-known Devonian fish locality in Estonia from where fish fossils were collected during the 19th century, e.g. by S. Kutorga in 1830-1840, H. Asmuss in 1836-1856, and C. Grewingk in 1856-1870 (Heintz, 1934).

The Karksi locality is situated in the village of Karksi about $30 \mathrm{~km}$ south of the town of Viljandi, on the right bank of the ancient valley of the Halliste River, $700 \mathrm{~m}$ upstream of the ruins of the Karksi Castle. The $8.3 \mathrm{~m}$ thick sequence of white and brownish-red sandstones, with intercalations of siltstones and clays, has been assigned to the Härma Beds of the Burtnieki Stage (Kleesment, 1995). The main level, containing fish fossils, is a conglomerate layer $3 \mathrm{~m}$ above the base of the sequence, composed of clay pebbles, up to $0.2 \mathrm{~m}$ in diameter, in white sandstone matrix (E. Kurik, pers. comm., 1996).

The Sulbi locality, presently not accessible, was located about $15 \mathrm{~km}$ NWW of the town of Võru, on the left bank of the Pühajõgi River, about $1 \mathrm{~km} \mathrm{SW}$ of the village of Sulbi. The fish fragments of different sizes have been collected from a $0.2 \mathrm{~m}$ thick conglomeratic bed in the basal $0.8 \mathrm{~m}$ thick part of light-grey sandstone. The underlying interval of greenishgrey and brownish-red siltstone with intercalations of clay is exposed in a thickness of $2 \mathrm{~m}$. The clastic sequence that was exposed in the Sulbi outcrop has been assigned to the Koorküla Beds of the Burtnieki Stage (E. Kurik, pers. comm., 1996). 
The Jõksi outcrop is located about $25 \mathrm{~km}$ SEE of the town of Võru, on the right bank of the Piusa River, $5 \mathrm{~km}$ downstream from the village of Vastseliina. The studied fish samples originate from the basal $1 \mathrm{~m}$ of the $8 \mathrm{~m}$ thick sequence of cross-bedded white, partly yellowish and reddish sandstone. This sandstone sequence has been assigned to the Sietin Member of the Gauja Stage (E. Kurik, pers. comm., 1996).

\section{METHODS}

Scanning electron microscopy and energy-dispersive X-ray spectroscopy. Fragments of compact bony plates were carefully cleaned from the rock matrix, cut with a diamond saw, polished with a diamond disk, etched with $\mathrm{HCl}$ or $\mathrm{H}_{2} \mathrm{O}_{2}$, covered with a thin layer of graphite or gold, and studied under the scanning electron microscope (SEM; Tesla BS 300). Energy dispersive X-ray spectroscopy (EDX) was used for identifying authigenic minerals in the cavities of the exoskeletons.

XRD analysis. Samples were ground by hand in a mortar. Pure quartz was added as an internal standard to some samples, since part of the samples contained it naturally. Several drops of ethyl alcohol were added to the powder and the resulting smooth slurry was applied to a glass slide.

The powder XRD analysis was carried by means of the X-ray diffractometer HZG4 (Freiberger Präzisionmechanik), using Fe-filtered Co-radiation. Intensities were measured in two $2 \Theta$ ranges: from 28 to 41 degrees and from 54 to 64 degrees, with 0.02 degree interval in a step scan mode. The measured XRD diffractogramme includes 15 reflections of apatite $(002,102,210,211,112,300,202,222,312,320,213,321,410$, $402,004)$ and the 101 and 112 reflections of quartz, which is used as the internal standard.

The discrete intensity data were processed using a multi-component curve-fitting method to obtain the exact values of the peak positions and half-widths (cf. Kallaste \& Kiipli, 1995). The measured peak positions and half-widths were corrected for the diffractometer drift and apparatuswidening using the 101 and 112 quartz reflections. The apatite lattice parameters were calculated using the least squares' method.

\section{RESULTS AND DISCUSSION}

According to the XRD analysis, all the studied skeletal fragments of the fossil Devonian fishes are composed of carbonate fluorapatite, with the lattice parameters $a$ and $c$ ranging from 9.360 to $9.374 \AA$ and from 6.891 to 
$6.895 \AA$, respectively (Table). Additionally, the presence of feldspars and dolomite was detected from XRD patterns of a part of skeletal fragments cleaned from the surrounding rock (Fig. 2). As compared with the previously reported values for the Devonian fishes (Sidorenko \& Chernova, 1962; Ivanov \& Pavlov, 1988), the variation range of the lattice parameter $a$ is smaller, with minimal locality- or taxon-dependent differences (Fig. $3 \mathrm{~A}, \mathrm{~B})$.



Fig. 2. XRD pattern of Schizosteus striatus (sample k08, Gorodenka 1 locality). Ap, apatite; Q, quartz; F, feldspar; Do, dolomite.

\section{PLATE I}

Fig. 1. Sample k18, Tartuosteus sp., Aruküla, Viljandi Beds, Aruküla Stage, $\times 700$. Polished and $\mathrm{H}_{2} \mathrm{O}_{2}$-etched surface.

Fig. 2. Sample k08, Schizosteus striatus, Gorodenka 1, Kernave Member, Narva Stage, $\times 200$. Polished and $\mathrm{H}_{2} \mathrm{O}_{2}$-etched surface.

Fig. 3. Sample k17, Pycnosteus palaeoformis, Aruküla, Viljandi Beds, Aruküla Stage, $\times 50$. Polished and $\mathrm{H}_{2} \mathrm{O}_{2}$-etched surface.

Fig. 4. A detail of Fig. 3: a dolomite crystal surrounded by collophanous calcium phosphate, $\times 5000$.

Fig. 5. Sample k03, Schizosteus striatus, Gorodenka 2, Kernave Member, Narva Stage, $\times 700$. $\mathrm{HCl}$-etched surface.

Fig. 6. Sample k27, Psammolepis venyukovi, Jõksi, Sietin Member, Gauja Stage, $\times 750$. HCl-etched surface. Note a cavity in the outer surface of a bony plate filled by hexagonal apatite crystals. 

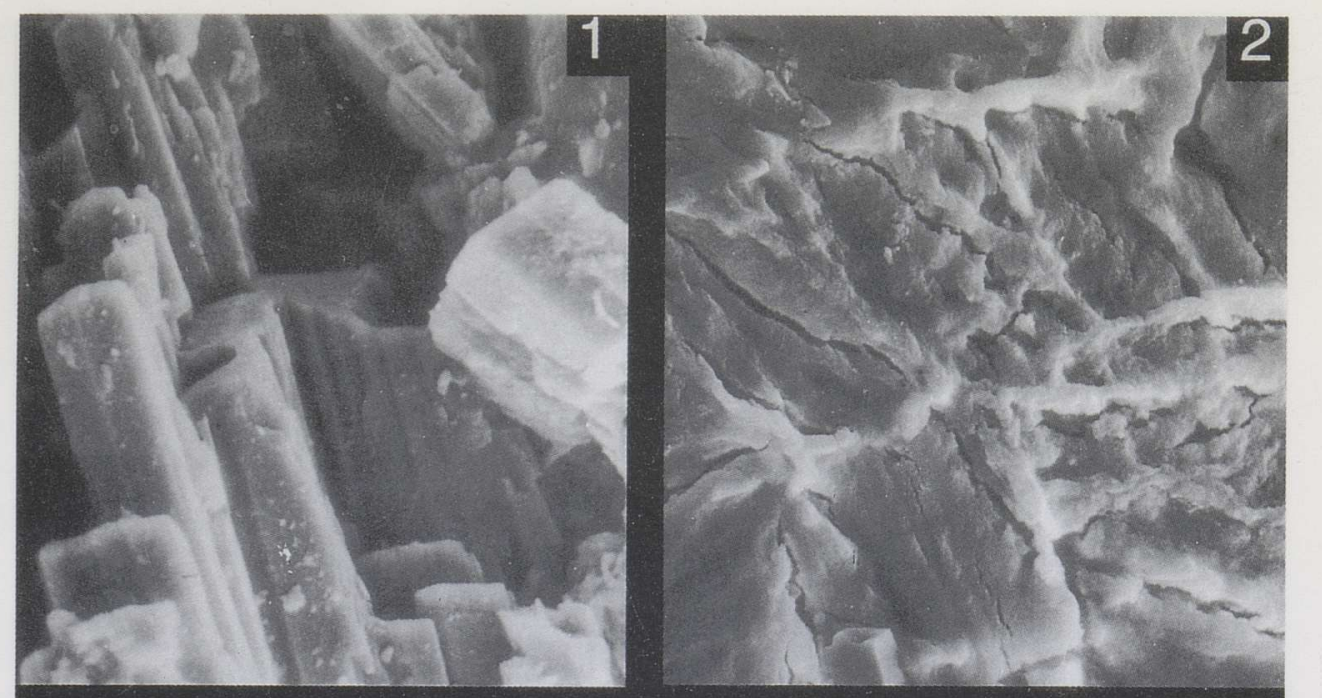


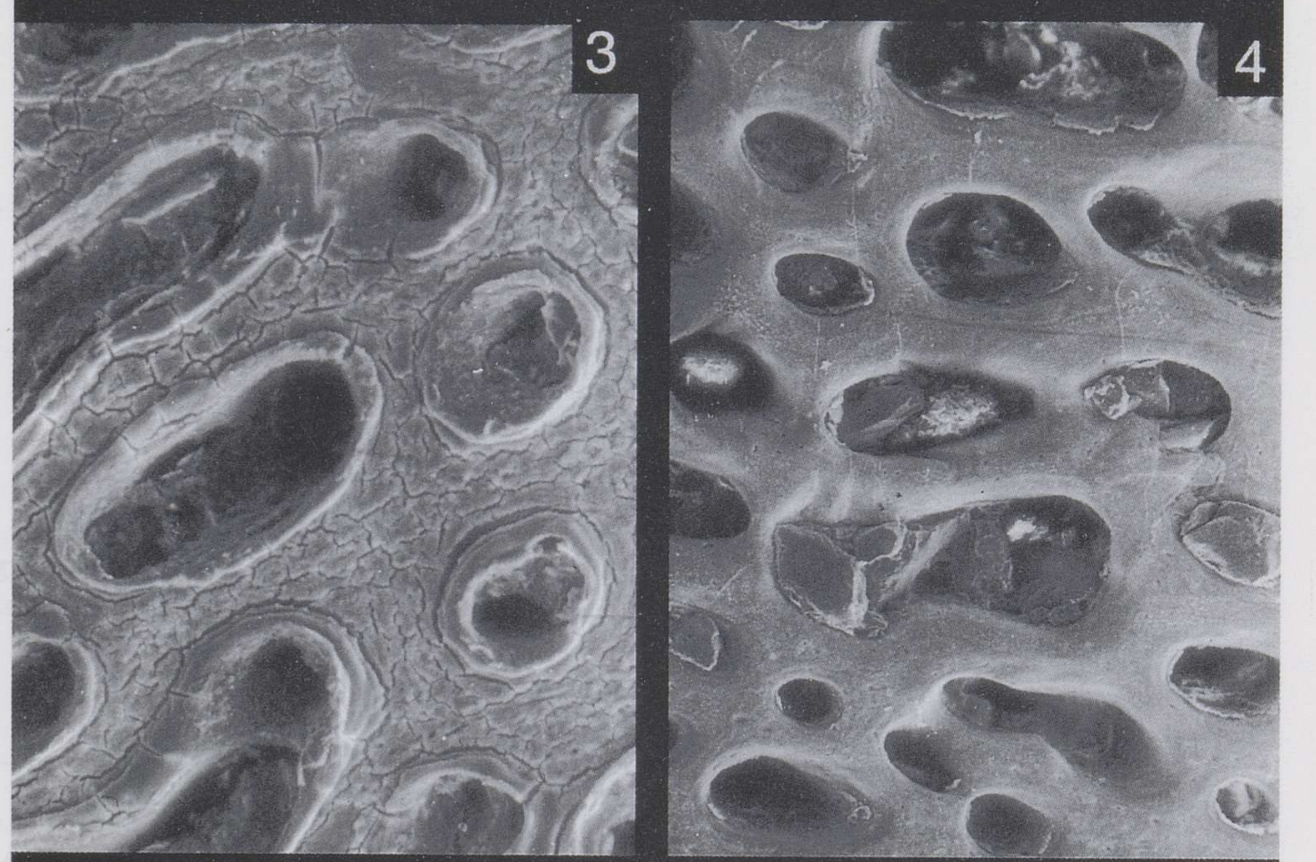

s.

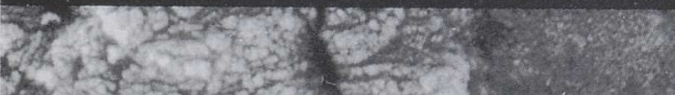

$7+2 x^{2}-3 x+2$

$1-2 \pi$ axyod

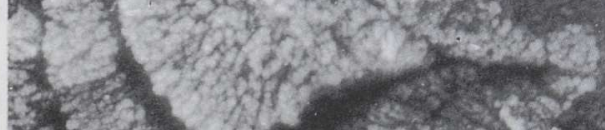

3.0.

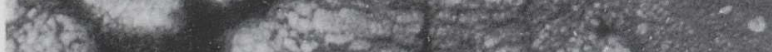

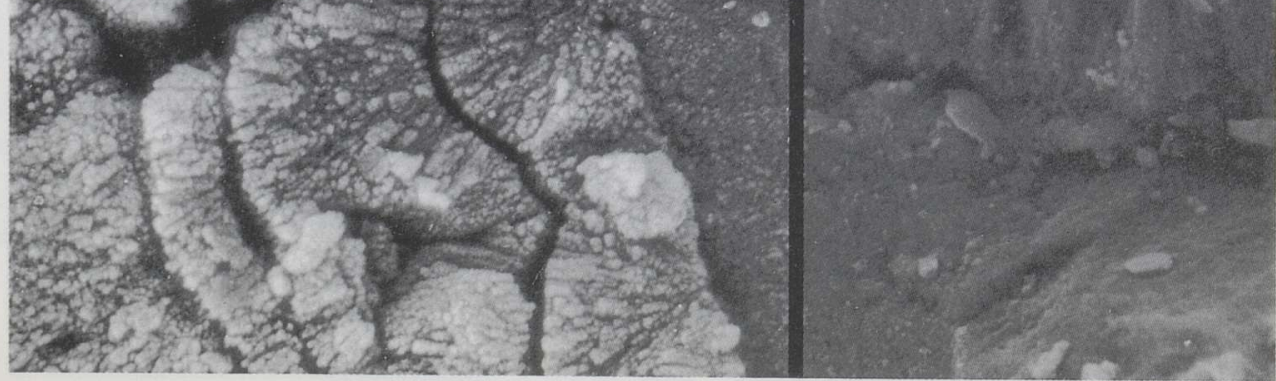




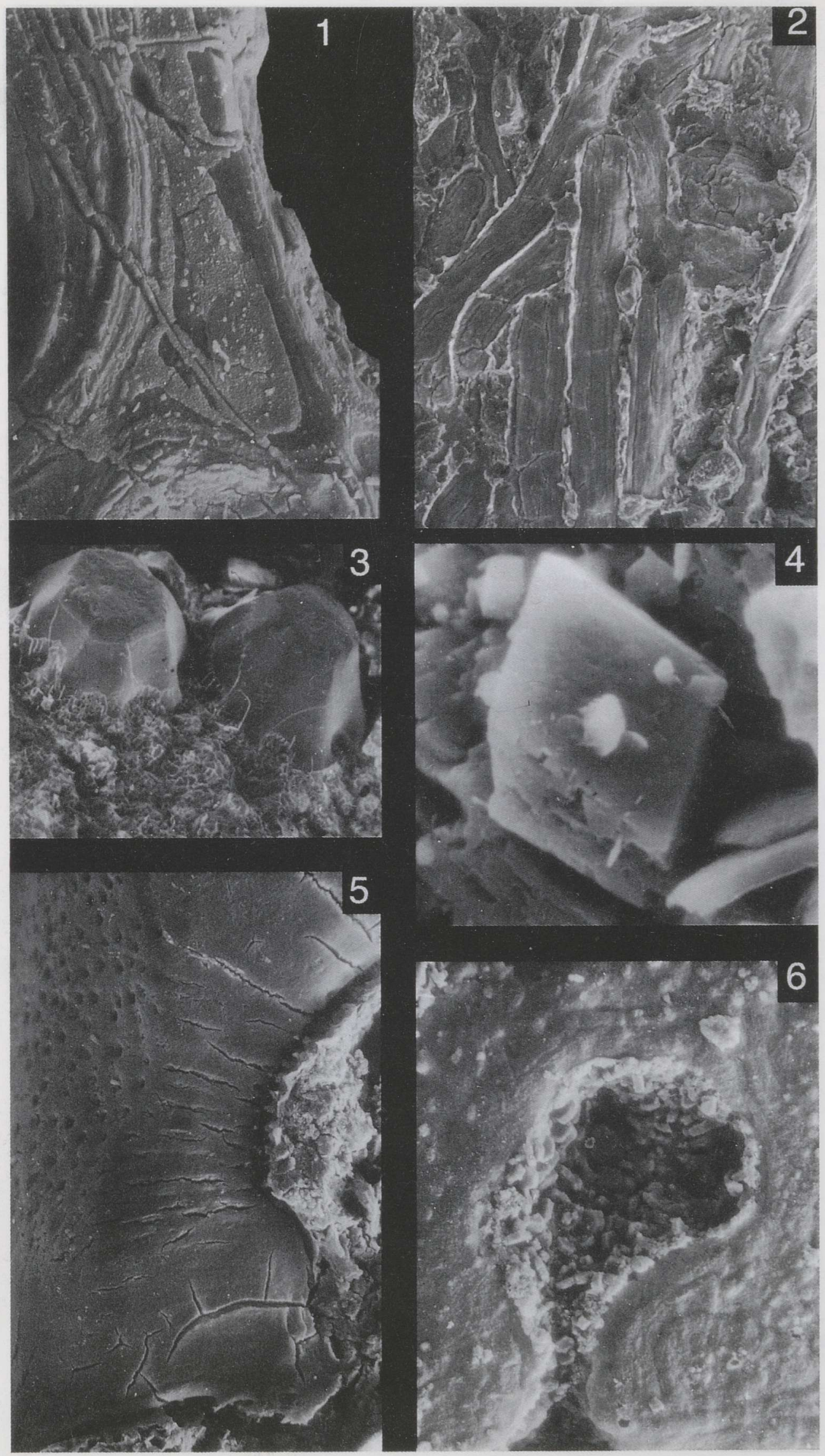





Fig. 3. Scatter plots of the apatite lattice parameters $a$ versus $c$ for the studied fish fossils, by higher taxa (A) and localities (B).

\section{PLATE II}

Fig. 1. Sample k18, Tartuosteus sp., Aruküla, Viljandi Beds, Aruküla Stage, $\times 1250$. $\mathrm{HCl}$-etched surface. Note possible phosphatized organic fibrils in the bony plate.

Fig. 2. Sample k07, Byssacanthus dilatatus, Gorodenka 1, Kernave Member, Narva Stage, $\times 1500$. Possible phosphatized organic framework.

Fig. 3. Sample k01, Holonema sp., Gorodenka 1, Kernave Member, Narva Stage, $\times 225$. Polished and $\mathrm{H}_{2} \mathrm{O}_{2}$-etched surface.

Fig. 4. Sample k06, Homostius latus, Gorodenka 2, Kernave Member, Narva Stage, $\times 125$. Polished and $\mathrm{HCl}$-etched surface.

Fig. 5. Sample k26, Laccognathus sp., Jõksi, Sietin Member, Gauja Stage, $\times 5000$. A multilayered dendritic phosphatic film in the interlayer space of a lamellar bone.

Fig. 6. Sample k26, Laccognathus sp., Jõksi, Sietin Member, Gauja Stage, $\times 1500$. A monolayered dendritic phosphatic film on the outer surface. 
Lattice parameters $(a, c)$ and the sizes of elementary crystallites across $(L a)$ and along $(L c)$ the apatite prism (in 410 and 004 directions, respectively)

\begin{tabular}{|c|c|c|c|c|c|c|}
\hline No. & Species & $a, \AA$ & $c, \AA$ & $L a, \AA$ & $L c, \AA$ & $L a / L c$ \\
\hline & \multicolumn{6}{|c|}{$\begin{array}{l}\text { Middle Devonian } \\
\text { Narva Stage } \\
\text { Gorodenka } 1 \text { locality }\end{array}$} \\
\hline k08 & Schizosteus striatus & $9.374(5)$ & $6.891(9)$ & ND & & \\
\hline k01 & Holonema sp. & $9.364(1)$ & $6.892(8)$ & 181 & 377 & 2.09 \\
\hline $\mathrm{k} 30$ & Homostius latus & $9.365(8)$ & $6.892(2)$ & 186 & 412 & 2.22 \\
\hline k07 & Byssacanthus dilatatus & $9.366(3)$ & $6.890(9)$ & 160 & 309 & 1.93 \\
\hline \multicolumn{7}{|c|}{ Gorodenka 2 locality } \\
\hline k03 & Schizosteus striatus & $9.367(5)$ & $6.891(5)$ & 166 & 338 & 2.04 \\
\hline k04 & Pycnolepis splendens & $9.367(3)$ & $6.892(8)$ & ND & & \\
\hline k06 & Homostius latus & $9.364(4)$ & $6.894(2)$ & 209 & 372 & 1.78 \\
\hline $\mathrm{k} 02$ & Glyptolepis sp. & $9.363(1)$ & $6.895(3)$ & 171 & 333 & 1.95 \\
\hline \multicolumn{7}{|c|}{$\begin{array}{l}\text { Aruküla Stage } \\
\text { Aruküla locality }\end{array}$} \\
\hline k19 & Homostius latus & $9.365(7)$ & $6.894(8)$ & 199 & 373 & 1.88 \\
\hline k16 & Byssacanthus dilatatus & $9.370(0)$ & $6.895(1)$ & 150 & 317 & 2.12 \\
\hline \multicolumn{7}{|c|}{$\begin{array}{c}\text { Burtnieki Stage } \\
\text { Karksi locality }\end{array}$} \\
\hline $\mathrm{k} 12$ & Pycnosteus tuberculatus & $9.361(9)$ & $6.891(6)$ & 186 & 262 & 1.41 \\
\hline k15 & Actinolepis magna & $9.362(2)$ & $6.891(8)$ & 195 & 339 & 1.74 \\
\hline k14 & Homostius latus & $9.368(2)$ & $6.893(0)$ & 150 & 292 & 1.94 \\
\hline \multirow[t]{2}{*}{$k 29$} & Holoptychiidae gen. et sp. indet. & $9.360(6)$ & $6.892(3)$ & 194 & 349 & 1.80 \\
\hline & \multicolumn{6}{|c|}{ Sulbi locality } \\
\hline $\mathrm{k} 21$ & Ganosteus stellatus & $9.366(8)$ & $6.892(2)$ & 202 & 456 & 2.26 \\
\hline $\mathrm{k} 23$ & Psammosteus sp. & $9.362(5)$ & $6.891(6)$ & 224 & 536 & 2.39 \\
\hline \multirow[t]{2}{*}{$\mathrm{k} 22$} & Homostius latus & $9.370(1)$ & $6.892(2)$ & 211 & 442 & 2.09 \\
\hline & \multicolumn{6}{|c|}{$\begin{array}{l}\text { Gauja Stage } \\
\text { Jõksi locality }\end{array}$} \\
\hline $\mathrm{k} 27$ & Psammolepis venyukovi & $9.360(9)$ & $6.894(8)$ & 318 & 716 & 2.25 \\
\hline \multirow[t]{2}{*}{$\mathrm{k} 28$} & Asterolepis ornata & $9.363(1)$ & $6.892(8)$ & ND & & \\
\hline & \multicolumn{6}{|c|}{ Recent species } \\
\hline \multirow[t]{2}{*}{ rkk } & Abramis brama & $9.42(3)$ & $6.89(3)$ & ND & & \\
\hline & \multicolumn{6}{|c|}{ Pacific Ocean, NE Australia } \\
\hline h03 & Isurus oxyrinchus & $9.402(7)$ & $6.880(1)$ & ND & & \\
\hline
\end{tabular}

ND, not determined. 
In contrast, the Recent fish scales are composed of carbonate hydroxyapatite, characterized by a significantly higher lattice parameter $a$ (Table). This systematic difference can be explained by substitution of different ions into the apatite lattice (e.g., Slansky, 1986; Hughes et al., 1989). The fluor-containing carbonate-OH-apatite in hard tissues of Recent vertebrates has a tendency to crystallographic maturation by replacement of $\mathrm{OH}$ by $\mathrm{F}$ and $\left(\mathrm{PO}_{4}\right)^{3-}$ by $\left(\mathrm{CO}_{3}\right)^{2-}$ and $\mathrm{F}^{-}$. Thus, additional $\mathrm{F}$ is incorporated into the lattice with carbonate, as apatite becomes carbonate fluorapatite. According to Lucas \& Prévôt (1991), this acquisition of $\mathrm{F}$ and carbonate can be initiated in vivo and continues during diagenesis.

The diffraction profiles for the Recent and fossil fishes show great differences (Fig. 4). A higher background signal reflects the presence of the organic matter in the tissues of the Recent fishes. Judging by the corresponding positions (diffraction properties) of the background humps, the part of the organic matrix not oxidized after treatment with $\mathrm{H}_{2} \mathrm{O}_{2}$ has preserved its epitaxial relationships with the apatite of the scales.

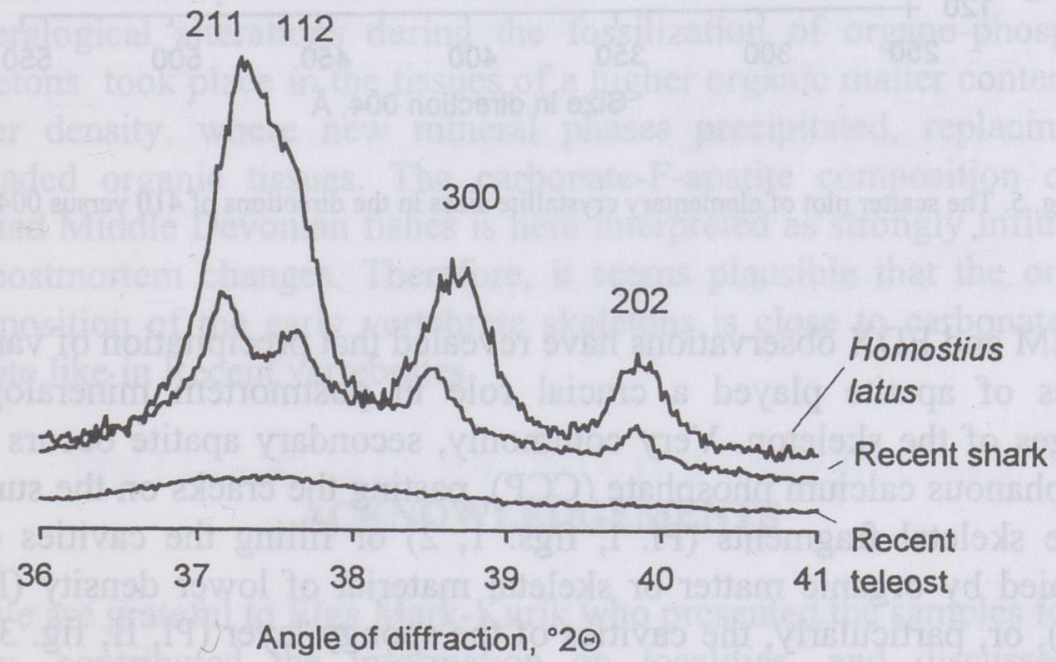

Fig. 4. The diffractograms of a Devonian arthrodire Homostius latus (sample k14), a Recent shark (sample h03), and a Recent teleost (bream, sample rk01).

Due to low crystallinity, the habitus of the elementary crystallites of apatite in the Recent shark and bream scales can be characterized only qualitatively. The scales of the Recent fishes are built up of crystallites of various shapes, apparently with taxon-specific dimensions.

The scales of the Recent bream are composed of needle-shaped prisms; crystallinity is significantly higher in the direction of 001 than in the direction of $\mathrm{hk} 0$. At the same time, some features of the diffraction profiles 
suggest that the Recent shark scales are composed of a mixture of elongate prisms of different length.

The elementary crystallites of the fossil fishes are elongate prisms of variable length. Two groups of the crystals with different habitus can be distinguished (Fig. 5, Table). The observed variations and habitus groups are neither taxon-specific nor locality-dependent.

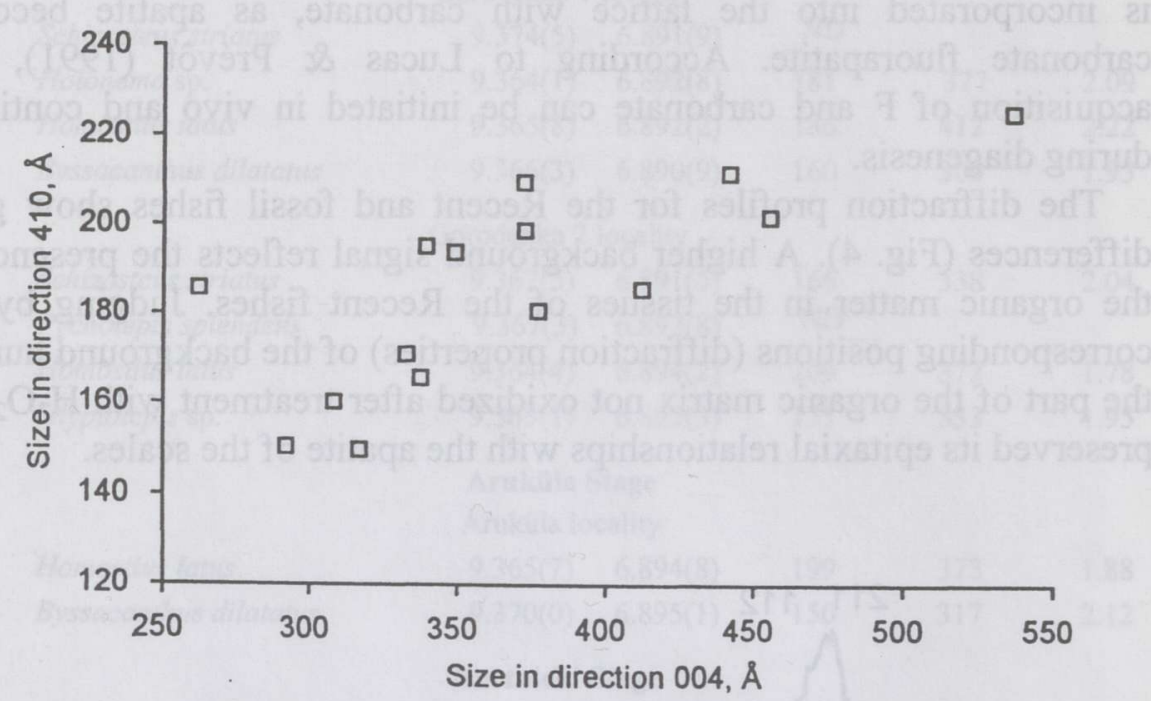

Fig. 5. The scatter plot of elementary crystallite sizes in the directions of 410 versus 004 .

SEM and EDX observations have revealed that precipitation of various phases of apatite played a crucial role in postmortem mineralogical changes of the skeleton. Very commonly, secondary apatite occurs as a collophanous calcium phosphate (CCP), pasting the cracks on the surface of the skeletal fragments (P1. I, figs. 1,2) or filling the cavities once occupied by organic matter or skeletal material of lower density (Pl. I, fig. 5), or, particularly, the cavities of the spongy layer (Pl. II, fig. 3). In some cases, apatite precipitated in the form of pinacoidal hexagonal prisms can be observed in the surficial parts of the skeletal fragments (Pl. I, fig. 6). Some fossil fish fragments give evidence of a selective dissolution of the skeletal tissues with a higher content of organic matter: in some cases only the tubercles consisting of dense apatite are preserved, whereas other tissues have been degraded and replaced by CCP-cemented skeleton fragments (P1. I, fig. 3).

In rare cases possible phosphatized organic structures can be observed (Pl. II, figs. 1, 2). The surface of some skeletal fragments is covered by apatite films formed by dendritic growth (P1. II, figs. 5, 6).

Among the non-phosphatic minerals, dolomite is the most common (Pl. I, fig. 4). Tiny feldspar and quartz crystals were observed in the 
cavities of the spongy layer (Pl. II, fig. 4). These minerals were identified both by SEM and EDX observations and XRD (Fig. 2).

The above observations of precipitation of various phases of authigenic apatite imply a wide range of possible diagenetic environments and scenarios. According to recent experimental studies (see Briggs \& Kear, 1993; Briggs, 1995 for recent reviews), phosphatization of soft tissues occurring in certain geochemical conditions has been considered as a geologically very rapid process, referred to as "Medusa effect" (Martill, $1988,1989)$. In most cases the organic tissues will rapidly mineralize; their degradation can contribute to the precipitation of secondary apatite phases.

The occurrence of at least two discrete apatite phases has been documented in the shells of Cambrian lingulate brachiopods where carbonate-F-apatite has precipitated to the space once occupied by organic matter (Ushatinskaya, 1995; Nemliher \& Puura, in press). A comparative study of the lattice parameters has revealed that the skeletal apatite composition tends to alterate from carbonate- $\mathrm{OH}$-apatite of the Recent lingulate shells towards carbonate-F-apatite in the fossil shells (Nemliher \& Puura, in press).

The evidence presented above allows us to conclude that the greatest mineralogical alterations during the fossilization of organo-phosphatic skeletons took place in the tissues of a higher organic matter content and lower density, where new mineral phases precipitated, replacing the degraded organic tissues. The carbonate-F-apatite composition of the studied Middle Devonian fishes is here interpreted as strongly influenced by postmortem changes. Therefore, it seems plausible that the original composition of the early vertebrate skeletons is close to carbonate- $\mathrm{OH}$ apatite like in Recent vertebrates.

\section{ACKNOWLEDGEMENTS}

We are grateful to Elga Mark-Kurik who presented the samples for this study, contributed the information on localities, and discussed the manuscript. Constructive comments by Enn Pirrus and Anne Kleesment are appreciated. For the technical assistance we thank Ursula Moldov (SEM), Gennadi Baranov (photography), and Heikki Bauert (figure drafting). This study was supported by the Estonian Science Foundation (grants No. 949 and 1663).

\section{REFERENCES}

Briggs, D. E. G. 1995. Experimental taphonomy. Palaios, 10, 6, 539-550.

Briggs, D. E. G. \& Kear, A. J. 1993. Fossilization of soft-tissue in the laboratory. Science, 259, 1439-1442. 
Heintz, A. 1934. Revision of the Estonian Arthrodira. Part I. Family Homostiidae Jaekel. Publications of the Geological Institution of the University of Tartu, 38, 1-115.

Hughes, J. M., Cameron, M. \& Crowley, K. D. 1989. Structural variations in natural F, OH and Cl apatites. American Mineralogist, 74, 870-876.

Ivanov, A. O. \& Pavlov, D. J. 1988. Investigation of mineral composition of vertebrate bone tissue. Vestnik Leningr. Univ. Geological-Geographical Series, 28, 7, 11-19 (in Russian).

Ivanov, A., Pavlov, D. \& Cherepanov, G. 1992. Some aspects of biomineralization of vertebrate exoskeleton. In Fossil Fishes as Living Animals (Mark-Kurik, E., ed.). Estonian Academy of Sciences, Tallinn, 159-165.

Kallaste, T. \& Kiipli, T. 1995. Discrete dolomite phases in carbonate rocks: Results of the mathematical treatment of X-ray diffraction peaks. Proc. Estonian Acad. Sci. Geol., 44, 4, 211-220.

Kleesment, A. 1994. Subdivision of the Aruküla Stage on the basis of lithological and mineralogical criteria. Proc. Estonian Acad. Sci. Geol., 43, 2, 57-68.

Kleesment, A. 1995. Lithological characteristics of the uppermost terrigenous Devonian complex in Estonia. Proc. Estonian Acad. Sci. Geol., 44, 4, 221-233.

Lucas, J. \& Prévôt, L. 1991. Phosphates and fossil preservation. In Taphonomy: Releasing the Data Locked in the Fossil Record (Allison, P. A. \& Briggs, D. E. G., eds.). Plenum Press, New York and London, 389-409.

Mark, E. 1952. Uusi arthrodiiriliike Tartu lademest (ENSV keskdevon). Tartu Riiklik Ülikool, Tartu (unpublished B.Sc thesis).

Martill, D. M. 1988. Preservation of fish in the Cretaceous Santana Formation of Brazil. Palaeontology, 31, 1, 1-18.

Martill, D. M. 1989. The Medusa effect: Instantaneous fossilization. Geology Today, 5, 201-205.

Nemliher, J. \& Puura, I. Shell mineralogy of lingulate brachiopods from the East Baltic CambrianOrdovician "Obolus phosphorite". Bulletin of the Geological Surveys of Greenland and Denmark (in press).

Sidorenko, G. A. \& Chernova, N. I. 1962. Rentgenograficheskoe izuchenie kostnogo fosfata iskopaemykh ryb Sovetskogo Soyuza. Rentgenografiya Mineral'nogo Syr'ya, 2, 7, 81-87 (in Russian).

Slansky, 1986. Geology of Sedimentary Phosphates. North Oxford Academic Publishers Ltd., London.

Ushatinskaya, G. T. 1995. The Earliest Lingulates. Nauka, Moscow.

\section{EESTI DEVONI KALADE DERMAALSE SKELETI MINERAALNE KOOSTIS}

\section{Jüri NEMLIHER, Tuuli LAAS, Toivo KALLASTE, Ivar PUURA}

Röntgenstruktuurianalüüsiga uuriti Eesti keskdevoni kalade dermaalse skeleti mineraalset koostist. Uuritud fossiilsed kalad koosnevad karbonaatfluorapatiidist võreparameetritega $a=9,360-9,374$ ja $c=6,891-6,895 \AA$. Elektronmikroskoopia ja röntgenspektroskoopia abil tuvastati, et fossiilsete kalade skeletifragmendid sisaldavad mitmeid autigeense tekkega apatiidi faase. Meie interpretatsiooni kohaselt võis devoni kalade skelett elu ajal koosneda karbonaat-hüdroksüülapatiidist nagu tänapäeva selgroogsetel. Fossiilsete kalade karbonaat-fluorapatiitset koostist võib seletada fossiliseerumise käigus toimunud muutustega, eelkõige autigeense karbonaat-fluorapatiidi tekkega. 


\section{МИНЕРАЛЬНЫЙ СОСТАВ ДЕРМАЛЬНОГО СКЕЛЕТА ДЕВОНСКИХ РЫБ ЭСТОНИИ}

Юри НЕМЛИХЕР, ТуУЛИ ЛААС, Тойво КАЛЛАСТЕ, Ивар ПУУРА

Рентгеноструктурным анализом изучен минеральный состав дермального скелета ископаемых рыб из среднего девона Эстонии. По данным исследования 28 фрагментов установлено, что скелет состоит из карбонат-фторапатита с параметрами кристаллической решетки $a=9,360-9,374$ и $c=6,891-6,895 \AA$. Электронномикроскопическими и рентгено-спектроскопическими исследованиями выявлены в ископаемых скелетных фрагментах различные модификации аутигенного апатита.

Высказано предположение, что прижизненный минеральный состав ископаемых рыб был близок к карбонат-гидроксиапатитовому, как у современных позвоночных. Карбонат-фторапатитовый состав объясняется посмертными тафономическими процессами, в частности, образованием вторичных фаз аутигенного карбонатфторапатита при деградации скелета. 